\title{
The JNK pathway represents a novel target in the treatment of rheumatoid arthritis through the suppression of MMP-3
}

Tomotake Kanai ${ }^{1}$, Naoki Kondo ${ }^{1 *}$ (D, Masayasu Okada ${ }^{2}$, Hiroshige Sano ${ }^{1}$, Go Okumura ${ }^{1}$, Yasufumi Kijima ${ }^{1}$, Akira Ogose $^{3}$, Hiroyuki Kawashima ${ }^{1}$ and Naoto Endo ${ }^{1}$

\begin{abstract}
Background and aim: The pathophysiology of rheumatoid arthritis (RA) is characterized by excess production of pro-inflammatory cytokines, including tumor necrosis factor-a (TNF-a), interleukin-1 $\beta$ (IL-1 $\beta$ ), and interleukin-6 (IL6) by neutrophils and macrophages in synovium. Additionally, these cytokines promote the production of reactive oxygen species (ROS), and increased production of matrix metalloproteinases (MMPs), including MMP-3, in synoviocytes that result in joint destruction. There is limited information on how proteolytic enzymes such as MMP3 can be regulated. We evaluated the effect of the antioxidant $N$-acetylcysteine (NAC) on RA and identified the relationship between the c-Jun $\mathrm{N}$ terminal kinase (JNK) pathway and MMP-3. We hypothesized that elucidating this relationship would lead to novel therapeutic approaches to RA treatment and management.
\end{abstract}

Methods: We investigated the effect of administering a low dose (1000 $\mu \mathrm{M}$ or less) of an antioxidant (NAC) to human rheumatoid fibroblast-like synoviocytes (MH7A cells). We also investigated the response of antioxidant genes such as nuclear factor erythroid -derived 2-related factor 2 (Nrf2) and Sequestosome 1 (p62). The influence of MMP-3 expression on the JNK pathway leading to joint destruction and the mechanisms underlying this relationship were investigated through primary dispersion culture cells collected from the synovial membranes of RA patients, consisting of rheumatoid arthritis-fibroblast-like synoviocytes (RA-FLS).

Results: Low-dose NAC (1000 $\mu \mathrm{M})$ increased the expression of Nrf2 and phospho-p62 in MH7A cells, activating antioxidant genes, suppressing the expression of MMP-3, and inhibiting the phosphorylation of JNK. ROS, MMP-3 expression, and IL-6 was suppressed by administering $30 \mu \mathrm{M}$ of SP600125 (a JNK inhibitor) in MH7A cells. Furthermore, the administration of SP600125 (30 $\mu \mathrm{M})$ to RA-FLS suppressed MMP-3.

Conclusions: We demonstrated the existence of an MMP-3 suppression mechanism that utilizes the JNK pathway in RA-FLS. We consider that the JNK pathway could be a target for future RA therapies.

Keywords: Low-dose NAC, MMP-3, JNK pathway, MH7A, RA-FLS

\section{Background}

Studies on the treatment of rheumatoid arthritis (RA) have focused on biological agents that suppress proinflammatory cytokines, including TNF $\alpha, \mathrm{IL}-1 \beta$, and IL$6[1-3]$. However, the suppression of oxidative stress, which causes inflammation, has not been sufficiently

\footnotetext{
* Correspondence: naokikondo1214@gmail.com

${ }^{1}$ Division of Orthopedic Surgery, Department of Regenerative and Transplant Medicine, Niigata University Graduate School of Medical and Dental Sciences, Chuo-ku, Niigata, Niigata, Japan

Full list of author information is available at the end of the article
}

investigated [3]. Antioxidants, including $N$-acetylcysteine (NAC) that eliminate reactive oxidative species (ROS), are used to suppress oxidative stress [4-6]. NAC directly suppresses and eliminates ROS [4, 7]. ROS promotes the production of matrix metalloproteinase- (MMP-) 3, a proteolytic enzyme that induces joint destruction and suppressing ROS might suppress MMP-3 [1-4, 8, 9].

In human synoviocytes stimulated with TNF $\alpha$, high dose of NAC (30 mM) administration suppressed nuclear factor-kappa B (NF- $\kappa B$ ) activation and production of TNF $\alpha$ and IL-6 proteins [10]. High doses of NAC 
have an anti-inflammatory effect; however, Sadowska et al. indicated that doses of $10 \mathrm{mM}$ and higher are cytotoxic. Zafarrullah et al. found that low doses of NAC (0.1$1 \mathrm{mM}$ ) regulated the redox state but doses higher than 10 $\mathrm{mM}$ resulted in structural alterations of TGF- $\beta[4,11]$. In a clinical setting, caution is required when determining the appropriate NAC dose.

The mitogen-activated kinase (MAPK) signal transduction pathway is associated with ROS activity and a p38 inhibitor suppressed ROS in HeLa cells treated with $\mathrm{H}_{2} \mathrm{O}_{2}$ [12]. JNK pathway stimulates inflammatory activity. It was prominently suppressed by administering NAC after hepatic ischemia-reperfusion injury in mice [7]. NAC treatment eliminates ROS and suppresses the JNK pathway and thereby protects granulosa cells from $\mathrm{H}_{2} \mathrm{O}_{2}$-induced apoptosis [13]. NAC affects the activity of MAPKs (mainly JNK); however, human synoviocytes display large individual differences in the expression of interleukins and MMPs. Owing to these differences, human synoviocytes were considered unsuitable for clarifying the mechanisms, including signal transduction and influence of the JNK pathway. For this reason, experiments were carried out on cell lines with less individual variation in the expression of interleukins and MMPs, particularly MH7A cells, which are human fibroblast-like synoviocytes. Our primary objective was to investigate the effect of low-dose NAC on RA. To achieve this, we attempted to confirm that MMP-3 expression is linked to anti-oxidative effects, anti-inflammatory activity, and joint destruction and determine its underlying MAPK signal transduction pathway. Our ultimate goal was to utilize the knowledge of signal transduction pathways to establish novel RA therapies using specific inhibitors.

\section{Methods}

\section{Cell culture and chemicals}

The MH7A rheumatoid fibroblast-like synoviocyte cell line was obtained from the Institute of Physical and Chemical Research (RIKEN, Tsukuba, Ibaraki, Japan). The pelleted MH7A cells were stored at $-80^{\circ} \mathrm{C}$ and cultivated in RPMI 1640 medium (Gibco, Grand Island, NY, USA) supplemented with $10 \%$ fetal bovine serum (FBS) (Biowest, Nuaillé, France) and 1\% antibiotic/antimycotic solution (Invitrogen, Carlsbad, CA, USA) in a humidified incubator with $95 \%$ air and $5 \% \mathrm{CO}_{2}$ at $37{ }^{\circ} \mathrm{C}$. After the fifth passage, MH7A cells were seeded into $3.5 \mathrm{~cm}$ dishes at a concentration of $3 \times 10^{5}$ cells/well and cultured for three days until $80-90 \%$ confluency was achieved. These cells were then examined.

Synovial tissues were obtained from two RA patients undergoing total knee arthroplasty and one patient undergoing synovectomy of the wrist. These patients had been diagnosed with RA according to the revised criteria of the American College of rheumatology [14] and had been treated with biologics, methotrexate, prednisolone, immunosuppressants, disease-modifying antirheumatic drugs (DMARDs), and nonsteroidal antiinflammatory drugs (NSAIDs) (Table 1).

Written informed consent was obtained from each patient before the specimens were collected in accordance with the protocols of the Niigata University Medical and Dental Hospital ethics committee. RA-FLS were isolated using the methods of Rosengren et al. [15] and Sano et al. [16]. Briefly, synovial tissues were cut into small pieces and digested with RPMI 1640 medium mixing collagenase $(1 \mathrm{mg} / \mathrm{mL})$ (Worthington Biochemical Corporation, Lakewood, NJ, USA) for $3 \mathrm{~h}$. The tissue was then filtered using a $70 \mu \mathrm{M}$ nylon cell strainer, washed, and suspended in RPMI 1640 medium. Dissociated cells were then centrifuged at $1500 \times g$ for $3 \mathrm{~min}$ twice and resuspended in RPMI 1640 medium supplemented with $10 \%$ FBS and 1\% antibiotic/antimycotic solution. Cells were cultured overnight, the non-adherent cells were removed, and the adherent cells were cultivated in RPMI 1640 medium supplemented with $10 \%$ FBS and 1\% antibiotic/antimycotic solution. After the fifth passage, RAFLS were seeded into $3.5 \mathrm{~cm}$ dishes at a concentration of $3 \times 10^{5}$ cells/well and cultured for 3 days until 80 $90 \%$ confluency was achieved. These cells were then examined.

NAC (Sigma-Aldrich, St. Louis, USA), a specific JNK inhibitor, SP600125 (Sigma-Aldrich), $\mathrm{H}_{2} \mathrm{O}_{2}$ (WAKO, Osaka, Japan), and dimethyl sulfoxide (DMSO; Meso Scale Discovery, Rockville, MD, USA) were used. Primary antibodies specifically recognizing IL-6 (Cell Signaling Technology, Danvers, MA, USA), MMP-3 (Cell Signaling Technology), Nrf2 (Abcam, Cambridge, UK), $\beta$-actin (Sigma-Aldrich), and phosphorylated antibody specifically recognizing phosphorylated forms of p62 (MBL, Nagoya, Japan), and JNK (Cell Signaling Technology) were also used.

\section{Evaluation of cell viability}

The effect of NAC on cell viability was determined using the XTT assay (Cell Proliferation Kit II, Roche Diagnostics, Basel, Switzerland), which is based on the reduction of a tetrazolium salt by mitochondrial dehydrogenase in viable cells. Cells were seeded into a 96-well plate at a density of $5 \times 10^{4}$ cells $/ \mathrm{mL}$ and treated with different concentrations of NAC ranging from $10 \mu \mathrm{M}$ to $10 \mathrm{mM}$ for $24 \mathrm{~h}$ at $37{ }^{\circ} \mathrm{C}$ in $5 \% \mathrm{CO}_{2}$. Then, $50 \mu \mathrm{L}$ of XTT stock solution $(0.3 \mathrm{mg} / \mathrm{mL})$ was added to each well to attain a total volume of $150 \mu \mathrm{L}$. After incubation for $18 \mathrm{~h}$, the optical density (OD) 450-500 was read on a scanning multi-well spectrophotometer (Model 680, Bio-Rad, Hercules, CA, USA). 
Table 1 Details of RA patients who collected synoviocytes

\begin{tabular}{|c|c|c|c|c|c|}
\hline & Sex & Age & Drug (pre-operation) & $\begin{array}{l}\text { CRP (mg/dl) } \\
\text { (pre-operation) }\end{array}$ & $\begin{array}{l}\text { ESR }(\mathrm{mm} / 1 \mathrm{~h}) \\
\text { (pre-operation) }\end{array}$ \\
\hline FLS 1 & Female & 43 & $\begin{array}{l}\text { Methotrexate } 10 \text { mg/week } \\
\text { Prednisolone } 5 \mathrm{mg} / \text { week } \\
\text { Bredinin } 450 \mathrm{mg} / \text { day } \\
\text { NSAIDs }\end{array}$ & 0.09 & 10 \\
\hline FLS 2 & Female & 56 & $\begin{array}{l}\text { Adalimumab } 40 \text { mg/2 week } \\
\text { Methotrexate } 8 \text { mg/day } \\
\text { NSAIDs }\end{array}$ & 0.21 & 5 \\
\hline FLS 3 & Female & 85 & $\begin{array}{l}\text { Iguratimod } 50 \text { mg/day } \\
\text { Bucillamine } 100 \text { mg/day }\end{array}$ & 1.54 & 91 \\
\hline
\end{tabular}

$C R P C$ reactive protein, ESR erythrocyte sedimentation rate

\section{Western blotting}

MH7A cells in $3.5 \mathrm{~cm}$ dishes were incubated with medium containing NAC or SP600125 for 3 and 24 h. RA-FLS in $3.5 \mathrm{~cm}$ dishes were incubated with medium containing SP600125 for 3 and $24 \mathrm{~h}$. Treated cells were washed with phosphate-buffered saline (PBS) (non-Ca and Mg) and harvested with a cell scraper. To prepare whole cell lysates, cell pellets were extracted with lysis buffer containing $1 \times$ Laemmli/urea (62.5 mM Tris, $\mathrm{pH}$ 6.8, 2\% sodium dodecyl sulfate, $5 \%$ glycerol, and $6 \mathrm{M}$ urea) and proteinase inhibitor $(4 \mu \mathrm{L})$. After measuring the protein concentration in the supernatant using the Pierce ${ }^{\mathrm{TM}}$ BCA Protein Assay Kit (Thermo Fisher Scientific, Waltham, MA, USA), the supernatants were mixed with $5 \%(\mathrm{v} / \mathrm{v}) 1 \mathrm{M}$ dithiothreitol and $5 \%(\mathrm{v} / \mathrm{v})$ bromophenol blue and heated at $98{ }^{\circ} \mathrm{C}$ for $5 \mathrm{~min}$. Equal amounts $(50 \mu \mathrm{g} /$ lane $)$ of proteins were separated by $10 \%$ sodium dodecyl sulfate-polyacrylamide gel electrophoresis (SDS-PAGE) and then electro-transferred onto nitrocellulose membranes. The membranes were incubated with the indicated primary antibodies (IL-6, MMP-3, Nrf2, phosphorylated p62, phosphorylated JNK) and further incubated with secondary G-horseradish peroxidase conjugates (Amersham $^{\mathrm{TM}}$, GE Healthcare, Little Chalfont, UK). Protein bands were visualized by Western blotting detection solution using an enhanced chemiluminescence Western blotting detection solution (Hi-RENDOL ${ }^{\circledR}$, Hi-RENFIX ${ }^{\oplus}$, Fujifilm, Tokyo, Japan) and exposing the membranes to Xray film or the protein signals were detected with an ECL system (BioRad, Hercules, CA, USA) and visualized using a charge-coupled device (CCD) cooled camera (Gene Genome; Syngene, Cambrigde, UK). These X-ray film data were digitalized and graphs were individually created using public domain image processing software, ImageJ (U. S. National Institutes of Health, Bethesda, Maryland, USA, http://imagej.nih.gov/ij/).

\section{Immunocytochemistry/immunofluorescence and visualization of Nrf2}

MH7A cells were cultured in chamber slides (SUPERFROST $^{\oplus}$, Matsunami Glass, Japan) for $24 \mathrm{~h}$ following pre-incubation for 3 and $24 \mathrm{~h}$ after the administering of
NAC $(1000 \mu \mathrm{M})$. Cells were again cultured for $1 \mathrm{~h}$ after the administering of $\mathrm{H}_{2} \mathrm{O}_{2}(100 \mu \mathrm{M})$. The cells were then fixed with $4 \%$ paraformaldehyde and permeabilized with Tris-buffered saline (TBS) containing $0.1 \%$ Triton $\mathrm{X}-100$. Nonspecific binding was blocked with $5 \%$ bovine serum albumin (BSA) dissolved in Dulbecco's phosphate-buffered saline (DPBS) for $30 \mathrm{~min}$. The slides were incubated for $1 \mathrm{~h}$ at $25{ }^{\circ} \mathrm{C}$ with primary antibody (anti-Nrf2, ab53019, Abcam). After three washes for 10 min each, the slides were incubated for $1 \mathrm{~h}$ with Alexa Fluor $^{\mathrm{TM}} 568$ Phalloidin supplemented with goat antirabbit IgG- Alexa Fluor 488(Thermo Fisher Scientific) secondary antibodies. Nuclei were stained with 4',6-diamidino-2-phenylindole (DAPI; Thermo Fisher Scientific). After three washes for $10 \mathrm{~min}$ each, the slides were covered with mounting medium (Dako, Glostrup, Denmark) and analyzed with a confocal laser scanning microscope (FLUOVIEW 1200, Olympus, Tokyo, Japan).

\section{Evaluation of ROS formation}

Quantitative ROS measurements for MH7A cells incubated in medium containing NAC or SP600125 for 3 and $24 \mathrm{~h}$ was performed using the Muse $^{\mathrm{Tm}}$ Oxidative Stress kit (EMD Millipore Bioscience, Billerica, MA, USA). This provided the relative percentages of cells that are ROS-negative and ROS-positive. After treatment with NAC or SP600125, MH7A cells were harvested, incubated with oxidative stress reagent (dihydroethidium), and analyzed on the Muse Cell Analyzer according to the manufacturer's protocol. To measure ROS, a reflection of oxidative stress, MH7A cells were incubated in medium containing NAC or SP600125 for 3 and $24 \mathrm{~h}$ each, and $\mathrm{H}_{2} \mathrm{O}_{2}$ was added to the medium for $1 \mathrm{~h}$ because the intracellular ROS level was highest $1 \mathrm{~h}$ after the addition of $\mathrm{H}_{2} \mathrm{O}_{2}[17,18]$.

\section{Chemiluminescent enzyme immunoassay}

The concentrations of IL- 6 in the MH7A cell culture supernatants were measured using a Fully Automated Chemiluminescent Enzyme Immunoassay system (LUMIPULSE $^{\oplus}$ G1200, Fujirebio, Inc., Tokyo, Japan). IL-6 in 
MH7A cells was measured after administering NAC (1000 $\mu \mathrm{M})$ for $24 \mathrm{~h}$ or SP600125 $(30 \mu \mathrm{M})$ following $24 \mathrm{~h}$ of treatment with $100 \mu \mathrm{M} \mathrm{H}_{2} \mathrm{O}_{2}$ to induce oxidative stress.

\section{Statistical analysis}

All measurements were replicated three or four times, and all values are expressed as the means \pm the standard error of the mean (SEM). Statistical analyses were performed with one-way analysis of variance to analyze (ANOVA) followed by Turkey's multiple comparisons test, and twoway ANOVA followed by Dunnett's, Turkey's, or Bonferroni's multiple comparisons test using GraphPad Prism software (GraphPad, Inc., San Diego, CA, USA). $P$ value $<.05$ was considered statistically significance.

\section{Results}

Determination of working concentration of $\mathrm{NAC}$ and $\mathrm{H}_{2} \mathrm{O}_{2}$ in MH7A cells

To determine the appropriate experimental concentrations of $\mathrm{NAC}$ and $\mathrm{H}_{2} \mathrm{O}_{2}$ for the experiment, we determined the cytotoxicity of these solutions. At a concentration of $10 \mathrm{mM}(10,000 \mu \mathrm{M}) \mathrm{NAC}$, cell viability of MH7A was $30 \%$ after $24 \mathrm{~h}$ of treatment (Fig. 1a(1)).
At a concentration of $1000 \mu \mathrm{M}$ or lower NAC, cell viability of MH7A was greater than $90 \%$. We, therefore, chose $1000 \mu \mathrm{M}$ or lower NAC as our working concentration (Fig. 1.a(2)). On the other hand, $\mathrm{H}_{2} \mathrm{O}_{2}$ is typically used at concentrations from 100 to $1500 \mu \mathrm{M}$ [13, 17, 18]. MH7A cell lived about only $40 \%$ by administering $100 \mu \mathrm{M}$ of $\mathrm{H}_{2} \mathrm{O}_{2}$ for $24 \mathrm{~h}$. We decided to use $100 \mu \mathrm{M}$ of $\mathrm{H}_{2} \mathrm{O}_{2}$ for a brief time (Fig. 1a(3)).

\section{Low-dose NAC increases Nrf2 and p62 (antioxidant-} related proteins) and suppresses ROS elevation following $\mathrm{H}_{2} \mathrm{O}_{2}$ treatment

Nrf2 protein expression showed dose- and timedependent increases at 3 and $24 \mathrm{~h}$ after the administration of NAC $(10-1000 \mu \mathrm{M})$. Its expression significantly increased at $24 \mathrm{~h}$ after administering NAC $(1000 \mu \mathrm{M})$ compared with that at $24 \mathrm{~h}$ without treatment of NAC (1.33 vs. $1.08, P=.036)$ (Fig. $1 \mathrm{~b}(1,2)$ ). Phosphorylation of p62 (serine 403-phosphorylated p62) also showed dose- and time-dependent increases at 3 and $24 \mathrm{~h}$ after the administration of NAC (10$1000 \mu \mathrm{M})$. Its expression significantly increased at 24 $\mathrm{h}$ after administering NAC $(1000 \mu \mathrm{M})$ compared with

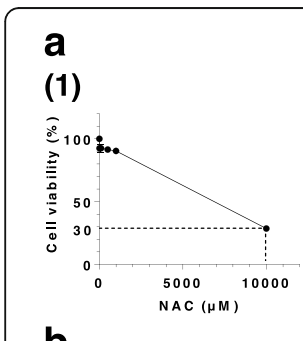

b

(1)

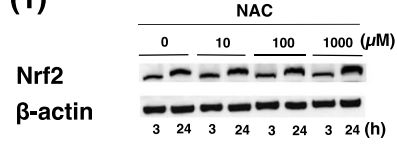

(2)

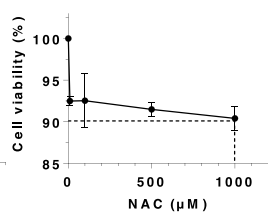

(3)

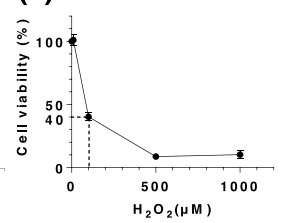

(2)

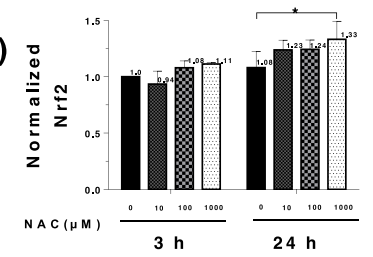

d

(1)

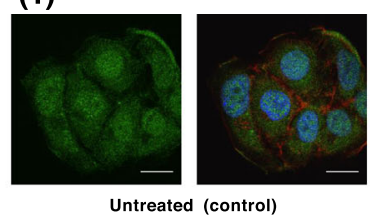

Nrf2 (green) / Phalloidin (red) / DAPI (blue)
(2)

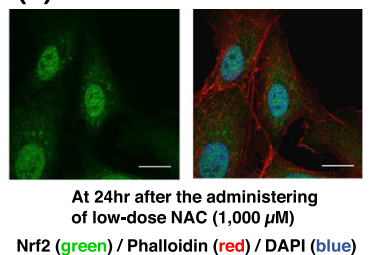

e

(1)

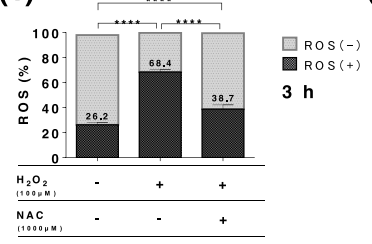

(2)

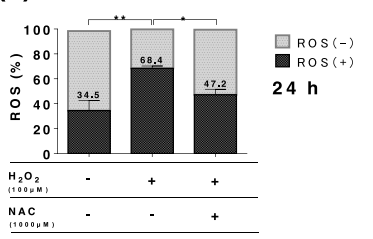

(1)

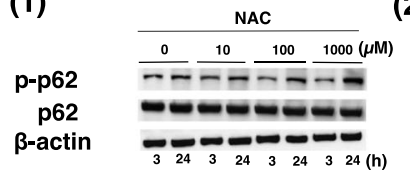

(2)

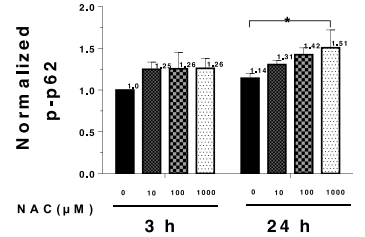

Fig. 1 Anti-oxidative effects of NAC. a(1) Cell viability graphs following NAC treatment at concentrations of 10, 100, 500, $1000 \mu \mathrm{M}$, and $10 \mathrm{mM}$ for $24 \mathrm{~h}$. All data are expressed as the mean $\pm \operatorname{SEM}(N=4)$. The dash-dotted line is a $10 \mathrm{mM} \mathrm{NAC}$ concentration producing $30 \%$ cell viability. a(2) This graph is an enlargement of $\mathbf{a}(1)$ below $1000 \mu \mathrm{M}$. The concentration of NAC showing less than $10 \%$ cytotoxicity was $1000 \mu \mathrm{M}$. $\mathbf{a}(3)$ The cell viability assay of $\mathrm{H}_{2} \mathrm{O}_{2} . \mathrm{H}_{2} \mathrm{O}_{2}$ more than $100 \mu \mathrm{M}$ was cytotoxic, killing $60 \%$ of cells in the sample. $\mathbf{b}(1), \mathbf{c}(1)$ An illustrative Western blotting picture of Nrf2 and phospho-p62 (p-p62) following NAC treatment (1000 $\mu \mathrm{M})$ for 3 or 24 h. b(2), c(2) Normalized values of Nrf2 or p-p62 were graphed $(N=3)$. Normalization was performed with Nrf2 or p-p62 band intensity of untreated cell (3-h incubation). $\mathbf{d}$ Immunocytochemistry of MH7A cells stained to identify Nrf2. The color analyzed by confocal laser scanning microscopy is expressed as Nrf2 (green)/phalloidin (red)/DAPI (blue). d(1) Untreated cells were cultured for $24 \mathrm{~h}$. $\mathbf{d}(2)$ Cells cultured for $24 \mathrm{~h}$ treated with low-dose NAC (1000 $\mu \mathrm{M})$ ). Scale bar; $20 \mu \mathrm{m}$. e ROS formation in MH7A cells following $\mathrm{H}_{2} \mathrm{O}_{2}$ treatment $(100 \mu \mathrm{M})$ for $1 \mathrm{~h}$ and low-dose NAC treatment $(1000 \mu \mathrm{M})$ for $3(\mathbf{e}(1))$ and $24 \mathrm{~h}(\mathbf{e}(2))$. All values are expressed as the mean $\pm \operatorname{SEM}(N=3)$. The significance levels are shown as ${ }^{*} P$ value $<.05,{ }^{* *} P$ value $<.01,{ }^{* * *} P$ value $<.001,{ }^{* * *} P$ value $<.0001$ 
that at $24 \mathrm{~h}$ without treatment of NAC (1.14 vs. 1.51, $P=.037)$ (Fig. 1c $(1,2)$ ).

Nrf2 expression was higher in cytoplasm than in nucleus after $24 \mathrm{~h}$ in untreated MH7A cells (Fig. 1d(1)). At $24 \mathrm{~h}$ after administering NAC $(1000 \mu \mathrm{M})$, Nrf2 was translocated from cytoplasm to nucleus reflecting antioxidant response (Fig. $1 \mathrm{~d}(2))$. This phenomenon is known to be always caused by oxidative stress.

The mean positive percentage of ROS in MH7A cells was $26.2 \%$ at $3 \mathrm{~h}$, and $34.5 \%$ at $24 \mathrm{~h}$, without NAC treatment. Compared with these control data, there was a significant increase in ROS (68.4\%) $1 \mathrm{~h}$ after the administering $\mathrm{H}_{2} \mathrm{O}_{2}(100 \mu \mathrm{M})(P<.0001)$. Pre-incubation with NAC $(1000 \mu \mathrm{M})$ for 3 and $24 \mathrm{~h}$ followed by $1 \mathrm{~h}$ of $\mathrm{H}_{2} \mathrm{O}_{2}$ $(100 \mu \mathrm{M})$ treatment resulted in significant decreases in ROS levels from 68.4 to $38.7 \%$ at $3 \mathrm{~h}(P<.0001)$, and from 68.4 to $47.2 \%$ at $24 \mathrm{~h}(P=.019)$, respectively (Fig. $1 \mathrm{e}(1,2))$. These results demonstrated that low-dose NAC $(1000 \mu \mathrm{M})$ suppressed the ROS elevation following $\mathrm{H}_{2} \mathrm{O}_{2}$ treatment $(100 \mu \mathrm{M})$ in MH7A cells.

Low-dose NAC suppresses MMP-3 protein expression and phosphorylation of JNK in MH7A cells

Expression of MMP-3 protein was not altered $3 \mathrm{~h}$ after administering NAC (10, 100, and $1000 \mu \mathrm{M})$; however, it decreased significantly after $24 \mathrm{~h}$ of NAC administration $(1000 \mu \mathrm{M})$ compared with that without NAC treatment $(0.45$ vs. 0.61 in the band expression intensity, $P=.03$ ) (Fig. 2a(1,2)). Phosphorylation of JNK $(54 \mathrm{kD})$ did not demonstrate significant dosedependent decrease at $3 \mathrm{~h}$ following low-dose NAC treatment. However, phosphorylation of JNK (46 kD) decreased significantly $3 \mathrm{~h}$ after NAC administration $(1000 \mu \mathrm{M})$ compared with those at $3 \mathrm{~h}$ without NAC treatment and $10 \mu \mathrm{M}$ NAC treatment $(1.0$ vs. 0.51 in the band expression intensity, $P=.049$, and 1.04 vs. $0.51, P=0.033$, respectively) (Fig. $2 b(1,2,3)$ ).

To investigate the change of IL-6 expression under treatment of NAC in MH7A cells, we performed the same experiments as MMP-3 and JNK proteins. Expression of IL- 6 protein was not significantly changed at 3 and $24 \mathrm{~h}$ after the administering of NAC $(10,100$, and $1000 \mu \mathrm{M})$ compared with the condition without NAC treatment (Fig. 2c(1, 2)).

$\mathrm{H}_{2} \mathrm{O}_{2}(100 \mu \mathrm{M})$ administration for $24 \mathrm{~h}$ significantly increased IL-6 concentration in supernatant of MH-7A cells compared with untreated condition (743 vs. 601 $\mathrm{pg} / \mathrm{ml}, P=.0047)$. NAC treatment $(1000 \mu \mathrm{M})$ for $24 \mathrm{~h}$ slightly decreased IL-6 concentration compared with the condition under $\mathrm{H}_{2} \mathrm{O}_{2}(100 \mu \mathrm{M})$ but no significant difference was detected (699 vs. $743 \mathrm{pg} / \mathrm{ml}$ ). These findings indicated that NAC was not able to reduce IL-6

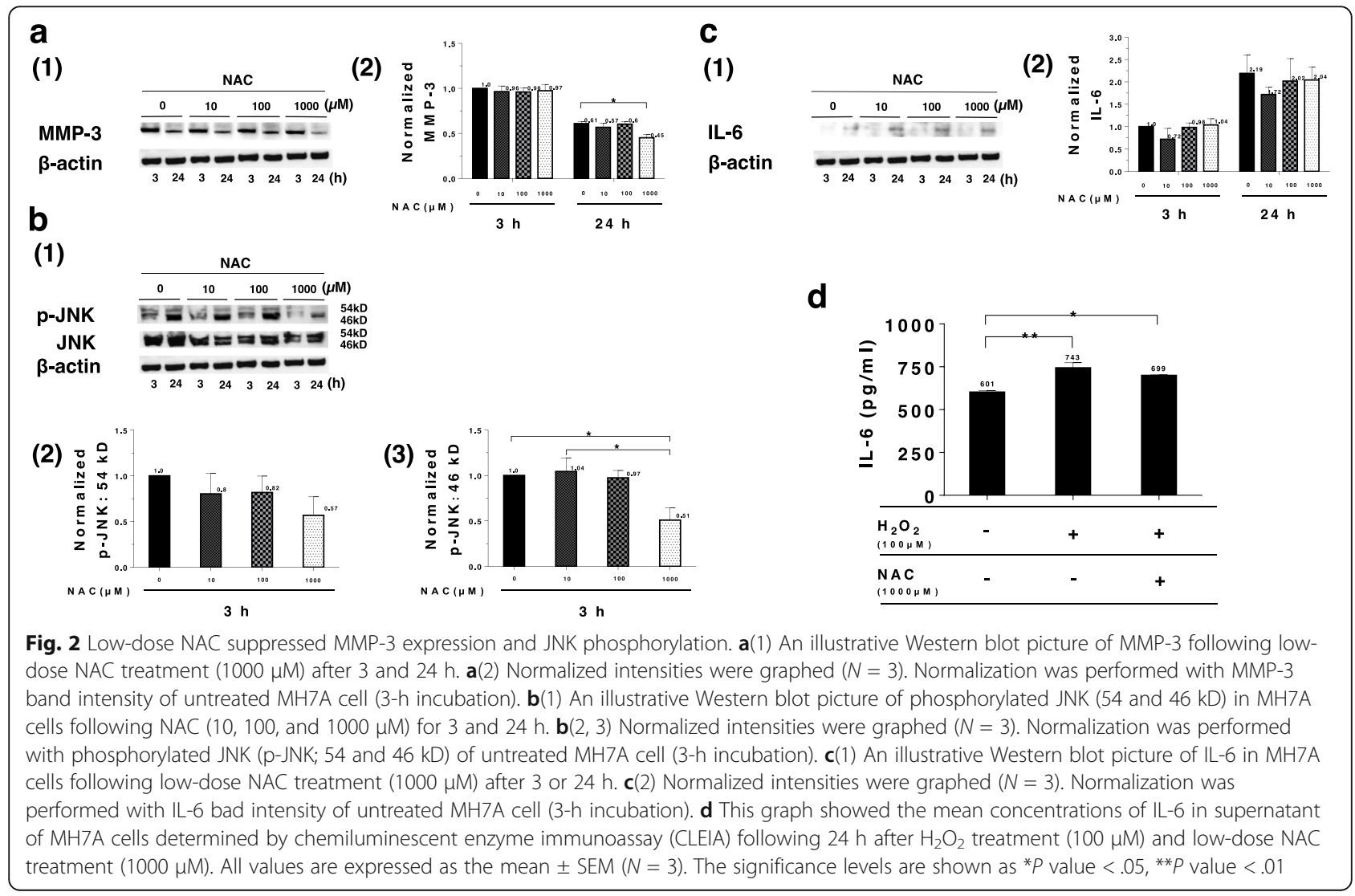


expression in cell lysates or IL-6 concentration in supernatants in MH-7A cells (Fig. 2d).

\section{JNK inhibitor (SP600125) has anti-oxidative and anti- inflammatory effects in MH7A cells}

JNK inhibitor (SP600125) concentrations of 15 and $30 \mu \mathrm{M}$ were selected based on the previous research $[19,20]$. SP600125 was dissolved in DMSO and used at a final concentration of $0.1 \%$ or less. Phosphorylation of JNK ( $54 \mathrm{kD}$ ) expression showed dose-dependent decrease by SP600125 treatment. The intensity of band expression of p-JNK $(54 \mathrm{kD})$ under $3 \mathrm{~h}$ treatment of $30 \mu \mathrm{M} \mathrm{SP} 600125$ was significantly decreased than those of untreated and $15 \mu \mathrm{M}$ SP600125 (0.53 vs. $0.87, P=.0026$ and 0.53 vs. $1.0, P=$ 0.0005 , respectively) (Fig. $3 \mathrm{a}(1,2)$ ). Phosphorylation of JNK (46 kD) expression also showed dose-dependent decrease by SP600125 treatment. The intensity of band expression of p-JNK $(46 \mathrm{kD})$ under $3 \mathrm{~h}$ treatment of $30 \mu \mathrm{M}$ SP600125 was significantly decreased than those of untreated and $15 \mu \mathrm{M}$ SP600125 (0.53 vs. $0.75, P=.004$ and 0.53 vs. $1.0, P<.0001$, respectively) (Fig. $3 \mathrm{a}(1,3)$ ). In addition, the intensity of band pattern of p-JNK $(46 \mathrm{kD})$ under $3 \mathrm{~h}$ treatment of $15 \mu \mathrm{M}$ SP600125 was also significantly decreased than that of untreated condition $(0.75$ vs. 1.0, $P=0.0025)$ (Fig. 3a(1, 3)).
There was no significant difference in phosphorylation of JNK ( 54 and $46 \mathrm{kD}$ ) at $24 \mathrm{~h}$ compared with $0.1 \%$ DMSO-treated cells (Fig. 3a(1)).

Next, we measured the rate of ROS positive cells to clarify whether JNK inhibitor has an antioxidative effect like NAC.

Compared to untreated MH7A cells, $1 \mathrm{~h}$ treatment of $\mathrm{H}_{2} \mathrm{O}_{2}(100 \mu \mathrm{M})$ significantly increased ROS to 66.4\% $(P<.0001)$. SP600125 $(15 \mu \mathrm{M})$ administration for $3 \mathrm{~h}$ significantly decreased $\mathrm{H}_{2} \mathrm{O}_{2}$-induced ROS to 48.3\% $(P<.0005)$. However, SP600125 $(30 \mu \mathrm{M})$ administration for $3 \mathrm{~h}$ did not significantly decrease $\mathrm{H}_{2} \mathrm{O}_{2}$-induced ROS (Fig. 3b(1)).

Compared to untreated MH7A cells, $1 \mathrm{~h}$ treatment of $\mathrm{H}_{2} \mathrm{O}_{2} \quad(100 \mu \mathrm{M})$ significantly increased ROS to 66.4\% $(P<.0001)$. SP600125 $(15 \mu \mathrm{M})$ administration for $24 \mathrm{~h}$ significantly decreased $\mathrm{H}_{2} \mathrm{O}_{2}$-induced ROS to 41.6\% $(P<.0001)$. SP600125 $(30 \mu \mathrm{M})$ administration for $24 \mathrm{~h}$ also significantly decrease $\mathrm{H}_{2} \mathrm{O}_{2}$-induced ROS to $38.7 \%(P<.0001)$ (Fig. 3b(2)).

These findings were confirmed by Western blotting of JNK proteins. Under identical conditions, phosphorylation of JNK (46 kD) in MH7A cells increased significantly $1 \mathrm{~h}$ after administering $\mathrm{H}_{2} \mathrm{O}_{2}(100 \mu \mathrm{M})$. However, phosphorylation of JNK decreased significantly $1 \mathrm{~h}$ after

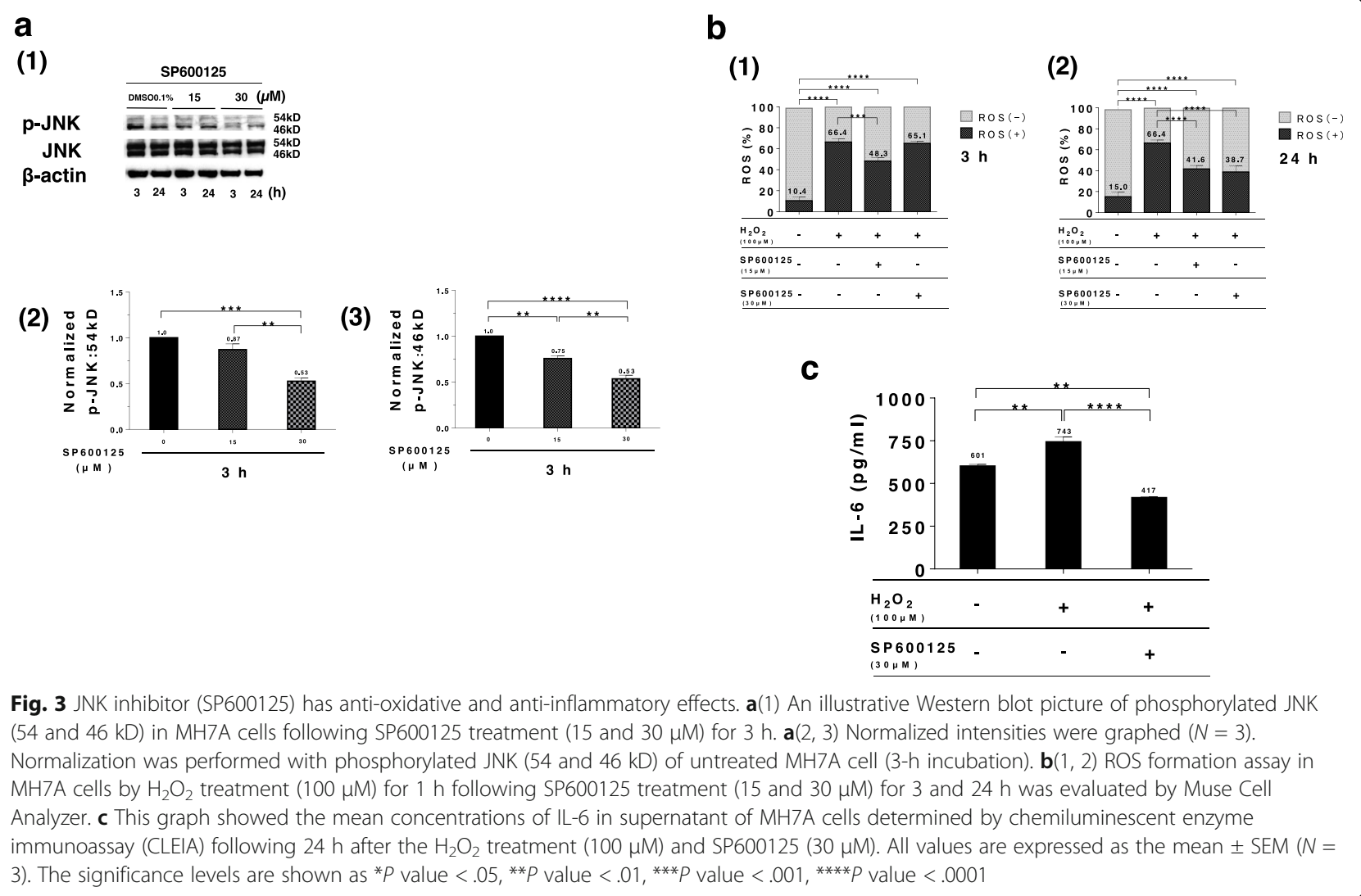


the administering of $\mathrm{H}_{2} \mathrm{O}_{2}(100 \mu \mathrm{M})$ and 3 and $24 \mathrm{~h}$ after administering SP600125 (15 or $30 \mu \mathrm{M}$ ) (Supplementary information: Fig. S1).

SP600125 treatment $(30 \mu \mathrm{M})$ for 24 h significantly decreased IL- 6 concentration compared with the condition under $\mathrm{H}_{2} \mathrm{O}_{2}(100 \mu \mathrm{M})$ for $24 \mathrm{~h}$ without SP600125 (417 vs. $743 \mathrm{pg} / \mathrm{ml}, P<.0001)$.

These findings indicated that SP100625 was able to reduce IL-6 concentration in supernatants in MH-7A cells (Fig. 3c).

\section{JNK inhibitor (SP600125) suppresses MMP-3 in both} MH7A cells and RA-FLS

In MH7A cells, protein expression of MMP-3 showed a dose-dependent decrease at 3 and 24 h. SP600125 (30 $\mu \mathrm{M})$ treatment for $24 \mathrm{~h}$ significantly decreased MMP-3 expression compared with untreated cells (0.51 vs. 0.93, $P=.0457)$, but not in the condition of SP600125 (30 $\mu \mathrm{M})$ treatment for $3 \mathrm{~h}$ (Fig. $4 \mathrm{a}(1,2)$ ).

In RA-FLS, protein expression of MMP-3 showed a dose-dependent decrease at 3 and $24 \mathrm{~h}$.

SP600125 $(30 \mu \mathrm{M})$ treatment for both 3 and $24 \mathrm{~h}$ significantly decreased MMP-3 expression compared with untreated cells $(0.52$ vs. $1.0, P=.0359$ at $3 \mathrm{~h}$ and 0.36 vs. $0.8, P=.0042$, respectively) (Fig. $4 \mathrm{~b}(1,2)$ ).

\section{Discussion}

We found that low doses of NAC $(1000 \mu \mathrm{M})$ and SP600125 (15 and $30 \mu \mathrm{M})$ were effective in suppressing the production of the proteolytic enzyme MMP-3, which, through suppression of JNK pathway component phosphorylation, causes joint destruction. The concentration of NAC required to suppress all proinflammatory cytokines and NF- $\mathrm{kB}$ is at least $5 \mathrm{mM}$. We determined that after $24 \mathrm{~h}$ of treatment, $10 \mathrm{mM}$ NAC is cytotoxic to MH7A cells with only $30 \%$ of MH7A cells remaining viable. We utilized a $1000 \mu \mathrm{M}$ concentration of NAC, which was cytotoxic to $10 \%$ or less of the MH7A cells in our sample. Low-dose NAC can reduce $\mathrm{H}_{2} \mathrm{O}_{2}$-induced $\mathrm{ROS}$ and increases in Nrf2 and p62 expression, which have antioxidant effects, and induce antioxidant genes (Fig. 1b, c, d) [21-26]. The expression of NF-kB is related to IL-6 production. Fujisawa et al. reported that low-dose NAC $(1000 \mu \mathrm{M})$ is unable to suppress the transcriptional activity of NF- $\mathrm{B}$, which was consistent with our findings (Fig. 2c, d) [10]. However, we found that low-dose NAC (1000 $\mu \mathrm{M})$ could significantly suppress the phosphorylation of JNK and downstream MMP-3 protein expression (Fig. 2a, b). These findings confirm

\section{a}

(1)

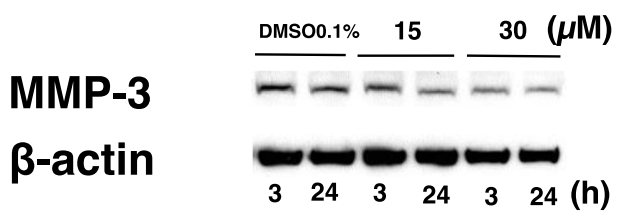

(2)

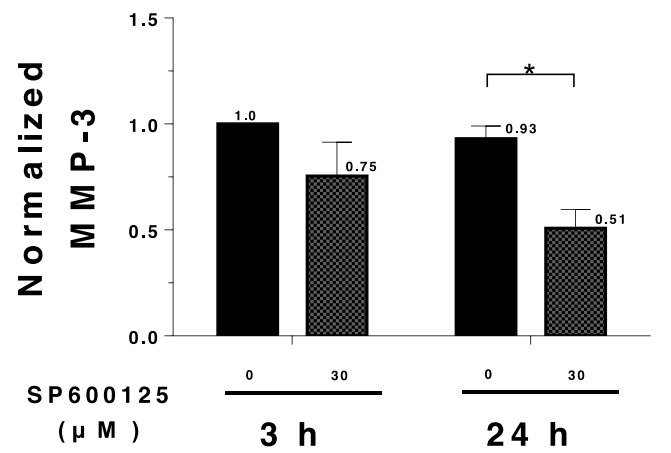

(1)

MMP-3

$\beta$-actin
SP600125

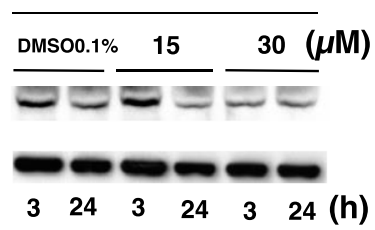

(2)

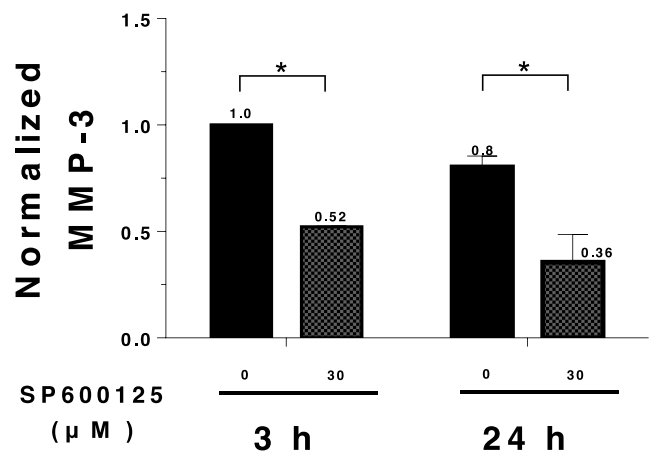

Fig. 4 JNK inhibitor suppresses MMP-3 in both MH7A cells and RA-FLS. a(1) An illustrative Western blot picture of MMP-3 following SP600125 treatment (15 and $30 \mu \mathrm{M})$ after 3 and $24 \mathrm{~h}$ in MH7A cells. a(2) Normalized intensities were graphed $(N=3)$. Normalization was performed with MMP-3 band intensity of untreated MH7A cell (3-h incubation). All values are expressed as the mean \pm SEM $(N=3)$. The significance levels are shown as *P value <.05. b(1) An illustrative Western blot picture of MMP-3 following SP600125 treatment (15 and $30 \mu \mathrm{M}$ ) after 3 and $24 \mathrm{~h}$ in RAFLS. $\mathbf{b}(2)$ Normalized intensities were graphed $(N=3)$. Normalization was performed with MMP-3 bad intensity of untreated RA-FLS cell (3-h incubation). All values are expressed as the mean $\pm \operatorname{SEM}(N=3)$. The significance levels are shown as ${ }^{*} P$ value $<.05$ 
that low-dose NAC is linked to the suppression of JNK phosphorylation and MMP-3 expression.

We conducted experiments using SP600125, a JNK inhibitor, to confirm that the suppression of JNK was directly inhibited MMP-3 expression. In MH7A cells, phosphorylation of JNK pathway components was significantly suppressed, dependent on dose, $3 \mathrm{~h}$ after SP600125 treatment (15 and $30 \mu \mathrm{M})$, and MMP-3 expression was significantly suppressed $24 \mathrm{~h}$ after administering SP600125 (30 $\mu \mathrm{M}$; Figs. 3a and 4a). ROS, which significantly increased $1 \mathrm{~h}$ after administering $\mathrm{H}_{2} \mathrm{O}_{2}(100 \mu \mathrm{M})$, was significantly suppressed $3 \mathrm{~h}$ after SP600125 treatment $(15 \mu \mathrm{M})$. At $24 \mathrm{~h}$ after administering SP600125 (15 and $30 \mu \mathrm{M})$, ROS was also significantly suppressed (Fig. 3b). The production of IL-6 in the cell supernatant was significantly inhibited $24 \mathrm{~h}$ after SP600125 treatment (30 $\mu \mathrm{M}$; Fig. 3c).

Findings acquired in our study demonstrated that low-dose NAC suppressed MMP-3 and ROS, but did not inhibit IL-6 and that SP600125 suppressed all the three MMP-3, ROS, and IL-6 in MH-7A cells. In particular, we confirmed that SP600125 $(30 \mu \mathrm{M})$ had an antioxidant, anti-inflammatory effect that suppressed ROS and inhibited IL-6 production (Fig. 3b, c, and S1). Experiments using RA-FLS obtained through the primary dispersion culture of synoviocytes taken from RA patients found that MMP-3 was significantly suppressed at 3 and $24 \mathrm{~h}$ following the administering of
SP600125 (30 $\mu \mathrm{M}$; Fig. 4b), which was similar results in the case of MH7A cells. We believe that this indicates the presence of an MMP-3 suppression mechanism that utilizes the JNK pathway in RA-FLS.

RA treatment must control both joint inflammation and joint destruction $[1-4,8-10]$. Shen $\mathrm{H}$ et al. indicated that JNK inhibitor (SP600125) suppressed the increase of activator protein-1 (AP-1) transcription factor unstream of MMPs production and the increase of NF-kB (p65) transcription factor unstream of IL-6 production due to paraquat injury in human lung basal epitherial calls. [27]. Using MH7A cells, RA synovial model cells, we demonstrated that a JNK inhibitor suppresses inflammation and joint destruction.

We finally considered the explainable mechanism of MMP-3 suppression via JNK pathway by low-dose NAC and JNK inhibitor (Fig. 5). MMP-3 expression is regulated by JNK pathway. Once ROS activate JNK-pathway, phosphorylated JNK activates nuclear transcription factor AP-1 and MMP-3 protein production is promoted. Low-dose NAC or JNK inhibitor (SP600125) inhibits ROS production itself and specifically inhibits phosphorylation of JNK protein so MMP-3 protein production is prominently suppressed.

\section{Conclusions}

MMP-3, which causes IL-6 production and joint destruction in RA patients, is produced by MH7A cells. In

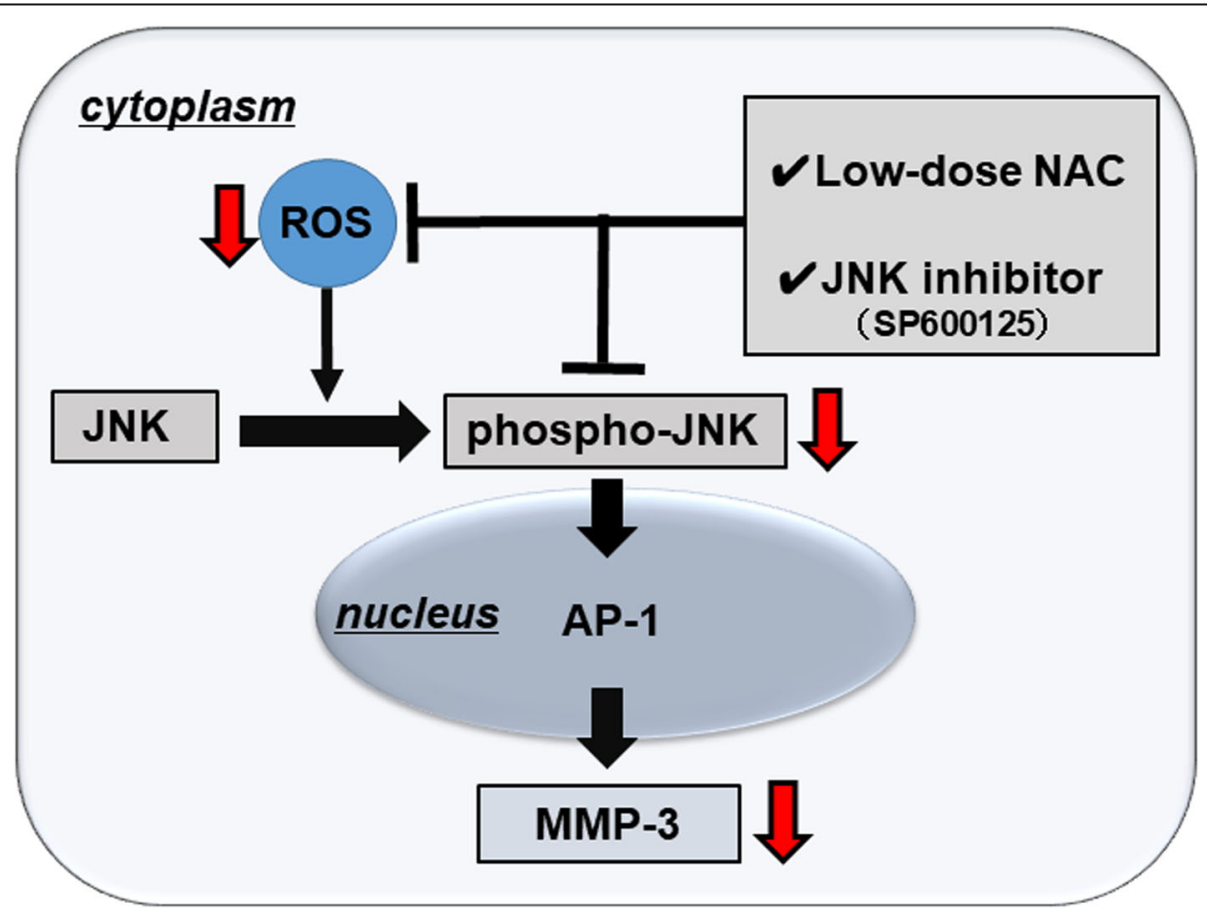

Fig. 5 Schema of MMP-3 suppression via the JNK pathway by low-dose NAC and JNK inhibitor 
MH7A cells, NAC reduces ROS and MMP-3. A JNK inhibitor reduces ROS production, decreases IL-6, and downregulates MMP-3. MMP-3 is also reduced in human synoviocytes collected from RA patients following the JNK inhibitor treatment. We believe that JNK pathway will be a novel therapeutic target for the treatment of RA.

\section{Supplementary information}

Supplementary information accompanies this paper at https://doi.org/10. 1186/s13018-020-01595-9.

Additional file 1: Fig. S1. An illustrative Western blot picture of p-JNK and $\mathrm{JNK}$ by $\mathrm{H}_{2} \mathrm{O}_{2}$ treatment $(100 \mu \mathrm{M})$ for $1 \mathrm{~h}$ following SP600125 treatment (15 and $30 \mu \mathrm{M}$ ) for 3 or $24 \mathrm{~h}$ in MH7A cells. SP600125 (15 and 30 $\mu \mathrm{M})$ suppressed phosphorylation of JNK that increased $1 \mathrm{~h}$ after administering of $\mathrm{H}_{2} \mathrm{O}_{2}(100 \mu M)$.

\section{Abbreviations}

AP-1: Activator protein -1; BSA: Bovine serum albumin; CLEIA: Chemiluminescent enzyme immunoassay; DAPI: 4',6-Diamidino-2phenylindole; DMARDs: Disease-modifying anti-rheumatic drugs; DMSO: Dimethyl sulfoxide; DPBS: Dulbecco's phosphate-buffered saline: FBS: Fetal bovine serum; JNK: c-Jun N terminal kinase; MAPK: Mitogenactivated kinase; MMPs: Matrix metalloproteinases ; NAC: N-acetylcysteine; NF-kB: nuclear factor-kappa B; Nrf2: Nuclear factor erythroid 2-related factor 2; NSAIDs: Nonsteroidal anti-inflammatory drugs; OD: Optical density; p62: Sequestosome 1; PBS: Phosphate-buffered saline; RA: Rheumatoid arthritis; RA-FLS: Rheumatoid arthritis-fibroblast-like synoviocytes; ROS: Reactive oxygen species; SDS-PAGE: Sodium dodecyl sulfatepolyacrylamide gel electrophoresis; SEM: Standard error of mean; TBS: Trisbuffered saline

\section{Acknowledgments}

The authors thank Mrs. Keiko Tanaka for providing technical assistance with qPCR and Western blotting and Mr. Takashi Ariizumi (M.D., Ph.D.) for providing technical assistance in various experiments.

\section{Ethics approval and consent to participants}

This study was approved by Institutional Review Board of Niigata University Medical and Dental Hospital (\#2018-0377). Written informed consent was obtained from each patient before the specimen was taken.

\section{Authors' contributions}

$\mathrm{TK}, \mathrm{MO}$, and $\mathrm{NK}$ designed the study. TK and MO performed experiment. HS, $\mathrm{GO}, \mathrm{YK}, \mathrm{AO}$, and HK . treated patients and collected the synovial tissues. TK, $\mathrm{MO}$ and NK interpreted data and wrote the manuscript. N.E. supervised this study. All authors read and approved the final manuscript.

\section{Funding}

We thank the Ministry of Education, Culture, Sports, and Science Technology who helped fund this research (18K09057 to N.K., 17 K17739 to M.O., 18 K09098 to A.O., and 17K10960 to H. K.)

\section{Availability of data and materials}

The datasets used during the current study are available from the corresponding author on reasonable request.

\section{Consent for publication}

Written informed consent was obtained from each patient for publication.

\section{Competing interests}

The authors declare that they have no competing interest.

\section{Author details}

'Division of Orthopedic Surgery, Department of Regenerative and Transplant Medicine, Niigata University Graduate School of Medical and Dental Sciences,
Chuo-ku, Niigata, Niigata, Japan. ²Department of Neurosurgery, Brain Research Institute, Niigata University, Chuo-ku, Niigata, Niigata, Japan. ${ }^{3}$ Department of Orthopedic Surgery, Uonuma Institute of Community Medicine, Niigata University Medical and Dental Hospital, Minami-Uonuma, Niigata, Japan

Received: 6 November 2019 Accepted: 13 February 2020

Published online: 04 March 2020

\section{References}

1. Filippin LI, Vercelino R, Marroni NP, Xavier RM. Redox signaling and the inflammatory response in rheumatoid arthritis. Clin Exp Immunol. 2008;152: 415-22.

2. Kobayashi M, Squires GR, Mousa A, Tanzer M, Zukour D, Antoniou J, Feige U, Poole R. Role of interleukin-1 and tumor necrosis factor a in matrix degradation of human osteoarthritic cartilage. Arthritis Rhum. 2005;52:128-35.

3. Quinonez-Flores CM, Gonzalez Chavez SA, Najera DDR, Pacheco-Tena C. Oxidative stress relevance in the pathogenesis of the rheumatoid arthritis: a systematic review. Bio Med Res Int. 2016;6097417:1-14.

4. Zafarullah M, Li WQ, Sylvester J, Ahmad M. Molecular mechanisms of Nacetylcysteine actions. CMLS. 2003;60:6-20.

5. Li J, Li J, Yue Y, Hu Y, Cheng W, Liu R, Pan X, Zhang P. Genistein suppresses tumor necrosis factor $a$-induced inflammation via modulating reactive oxygen species/Akt/nuclear factor kB and adenosine monophosphateactivated protein kinase signal pathways in human synoviocyte MH7A cells. Drug Des Devel Ther. 2014:8:315-23.

6. Orihuela-Campos RC, Tamaki N, Mukai R, Fukui M, Miki K, Terao J, Ito H. Biological impacts of resveratrol, quercetin, and $\mathrm{N}$-acetylcysteine on oxidative stress in human gingival fibroblasts. J Clin Biochem Nutr. 2015;56: 220-7.

7. Wang C, Chen K, Xia Y, Dai W, Wang F, Shen M, Cheng P, Wang J, Lu J, Zhang Y, Yang J, Zhu R, Zhang H, Li J, Zheng Y, Zhou Y, Guo C. Nacetylcysteine attenuates ischemia-reperfusion induced apoptosis and autophagy in mouse liver via regulation of the ROS / JNK / BCl-2 pathway. PLoS One. 2014;9:e108855.

8. Chambers M, Kirkpartrick G, Evans M, Gorshi G, Foater S, Borghaei RC. IL-4 inhibition of IL-1 induced Matrix Metalloproteinase-3 (MMP-3) expression in human fibroblasts involvers decreased AP-1 activation via negative crosstalk involving of Jun N-terminal Kinase (JNK). Exp Cell Res. 2013;319:1398-408.

9. Rose BJ, Kooyman DL. A tale of two joints: The role of matrix metalloproteases in cartilage biology. Dis Markers. 2016;4895050:1-7.

10. Fujisawa $\mathrm{K}$, Aono H, Hasunuma T, Yamamoto K, Mita S, Nishioka K. Activation of transcription factor NF-k B in human synovial cells in response to tumor necrosis factor a. Arthritis Rheum. 1996:39:197-203.

11. Sadowska AM, Manuel-y-Keenoy B, De Backer WA. Antioxidant and antiinflammatory efficacy of NAC in the treatment of COPD: Discordant in vitro and in vivo dose-effects: A review. Pulm Pharmacol Ther. 2007;20:9-22.

12. Hashimoto S, Gon Y, Mastumoto K, Takeshita I, Horie T. N-acetylcysteine attenuates TNF-a-induced p38 MAP kinase activation and p38 MAP kinasemediated IL-8 production by human pulmonary vascular endothelial cells. Br J Pharmacol. 2001;132:270-6.

13. Yang $H$, Xie $Y$, Yang D, Ren D. Oxidative stress-induced apoptosis in granulosa cells involves JNK, p53 and Puma. Oncotarget. 2017;8:25310-22.

14. Arnett FC, Edworthy SM, Bloch DA, McSane DJ, Fries JF, Cooper NS, Healey LA, Kaplan SR, Liang MH, Luthra HS. The American Rheumatism Association 1987 revised criteria for the classification of rheumatoid arthritis. Arthritis Rheum. 1988;31:315-24.

15. Rosengren S, Boyle DL, Firestein GS. Acquisition, culture, and phenotyping of synovial fibroblasts. Methods Mol Med. 2007:135:365-75.

16. Sano H, Kondo N, Fijisawa J, Netsu T, Kijima Y, Kanai T, Arai K, Endo N. Secretion of vascular endothelial growth factor is inhibited by the antioxidant of $\mathrm{N}$-acetylcysteine in fibroblast-like synoviocytes from rheumatoid arthritis. AJSR. 2016. https://doi.org/10.15413/ajsr.2016.0605.

17. Sato M, Miyazaki T, Nagaya T, Murata Y, Ida N, Maeda K, Seo H. Antioxidants inhibit tumor necrosis factor-a mediated stimulation of interleukin-8, monocyte chemoattractant protein-1, and collagenase expression in cultured human synovial cells. Am J Rheumatol. 1996;23:432-8.

18. Huang YH, Wu PY, Wen KC, Lin CY, Chiang HM. Protective effects and mechanisms of Terminalia catappa L. methenolic extract on hydrogenperoxide-induced oxidative stress in human skin fibroblasts. BMC Complement Altern Med. 2018;18:266. 
19. Han Z, Bolye DL, Chang L, Bennett B, Karin M, Yang L, Manning AM, Firestein GS. c-Jun N-terminal kinase is requited for metalloproteinase expression and joint destruction in inflammatory arthritis. J Clin Invest. 2001; 108:73-81.

20. Du L, Lyle CS, Obey TB, Gaarde WA, Muir JA, Bennett BL, Chambers TC. Inhibition of cell proliferation and cell cycle progression by specific inhibition of basal JNK activity. J Biol Chem. 2004;279:11957-66.

21. Komatsu M, Kurokawa H, Waguri S, Taguchi K, Kobayashi A, Ichmura Y. The selective autophagy substrate p62 activates the stress responsive transcription factor Nrf2 through inactivation of Keap1. Nat Cell Biol. 2010; 12:213-23.

22. Matsumoto G, Koji W, Okuno M, Kurosawa M, Nukina N. Serine 403 phosphorylation of p62/SQSTM1 regulates selective autophagic clearance of ubiquitinated proteins. Mol Cell. 2011;44:279-89.

23. Keum YS, Choi BY. Molecular and chemical regulation of the Keap1-Nrf2 signaling pathway. Molecules. 2014;19:10074-89.

24. Zhang L, Zhu Z, Liu J, Zhu Z, Hu Z. Protective effect of N-acetlcysteine (NAC) on renal ischemia/reperfusion injury through Nrf2 signaling pathway. J Recept Signal Transduct Res. 2014;34(s):396-400.

25. Itoh K, Ye P, Matsumia T, Tanji K, Ozaki T. Emerging functional cross-talk between the Keap1-Nrf2 system and mitochondria. J Clin Biochem Nutr. 2015:56:91-7.

26. Vomund S, Schäffer A, Parnham MJ, Brüne B, Knethen AV. Nrf2, the master regulator of anti-oxidative responses. Int J Mol Sci. 2017:18:2772

27. Shen H, Wu N, Wang Y, Han X, Zheng Q, Cai X, Zhang H, Zhao M. JNK inhibitor SP600125 attenuates paraquat-induced acute lung injury: an in vivo and in vitro study. Inflammation. 2017;40:1319-30.

\section{Publisher's Note}

Springer Nature remains neutral with regard to jurisdictional claims in published maps and institutional affiliations.

Ready to submit your research? Choose BMC and benefit from:

- fast, convenient online submission

- thorough peer review by experienced researchers in your field

- rapid publication on acceptance

- support for research data, including large and complex data types

- gold Open Access which fosters wider collaboration and increased citations

- maximum visibility for your research: over $100 \mathrm{M}$ website views per year

At BMC, research is always in progress.

Learn more biomedcentral.com/submissions 